\title{
KONSEPSI NEGARA KESEJAHTERAAN PADA KONTEKS PEMBANGUNAN WILAYAH
}

\author{
Irwan Suhermi, SE, M.Si \\ irwansuhermi@gmail.com \\ Universitas Teuku Umar
}

\begin{abstract}
The implementation of regional development in Indonesia can not be separated from the process of adoption from the development theory that developed by west experts in the regional planning. In the era of regional autonomy, regional development plays a very important in the development of Indonesia. By using secondary data, this paper tries to explore the development of the region conducted in Indonesia is associated with the concept of a welfare state

. The paper ends with a proposed regional development strategy in the future.
\end{abstract}

Kata kunci: Negara kesejahteraan, pembangunan wilayah

\section{PENDAHULUAN}

Usaha pembangunan di Indonesia bukan saja dilakukan dalam perencanaan pembangunan yang bersifat jangka panjang maupun jangka pendek, berdimensi makro dan mikro, tetapi juga mencakup perencanaan pembangunan yang berdimensi wilayah. Dalam kaitan ini, perencanaan pembangunan wilayah di Indonesia tidak akan terlepas dari pembangunan nasional mengingat pembangunan nasional pada hakekatnya bertumpu pada pembangunan wilayah.

Hal ini diperkuat dengan dilahirkannya Undang-Undang Nomor 32 tahun 2004 tentang Pemerintahan Daerah, Undang-Undang Nomor 33 tahun 2004 tentang perimbangan keuangan antara pemerintah pusat dan daerah serta UndangUndang Nomor 25 tahun 2004 tentang Sistem Perancanaan Pembangunan Nasional (SPPN) yang merupakan landasan hukum perencanaan pembangunan, baik oleh pemerintah pusat maupun pemerintah daerah. Sistem Perencanaan Pembangunan Nasional (SPPN) adalah satu kesatuan tata cara perencanaan pembangunan untuk menghasilkan rencana-rencana pembangunan dalam jangka panjang, jangka menengah dan tahunan yang dilaksanakan oleh unsur penyelenggara negara dan masyarakat di tingkat Pusat dan Daerah.

Pada hakekatnya SPPN ini merupakan dokumen yang berisikan tentang rencana-rencana pembangunan. Untuk menyelaraskan antara rencana pembangunan dan lokasi dilaksanakannya rencana pembangunan tersebut, lahirlah UndangUndang Nomor 26 Tahun 2007 tentang Penataan Ruang. Undang-undang penataan ruang ini pada hakekatnya mengendalikan, mengarahkan dan memanfaatkan ruang dalam proses dan pencapaian tujuan pembangunan nasional.

Makalah ini diawali dengan kajian empiris pembangunan wilayah yang dilaksanakan di Indonesia dilanjutkan dengan tantangan yang dihadapi dalam pembangunan wilayah serta diakhiri dengan penyusunan arah dan kebijakan pembangunan wilayah di masa yang datang. 


\section{HASIL DAN PEMBAHASAN Kajian Empiris Pembangunan Wilayah Di Indonesia: Antara Teori Dan Praktik}

Perkembangan konsep pengembangan wilayah di Indonesia merupakan adopsi dan adaptasi dari teori yang dikembangkan oleh beberapa ahli. Perkembangan perencanaan wilayah juga tidak terlepas dari perkembangan ilmu ekonomi regional. Istilah ilmu ekonomi regional sebagai peralatan analisa kadang disebut dengan istilah Regional Science (yang lebih menekankan analisanya pada aspek sosial ekonomi dan geografi) ${ }^{1}$ dan Regional Planning (yang menekankan analisanya pada aspek tata ruang, tata guna lahan dan perencanaan ${ }^{2}$.

Sebenarnya, terdapat banyak teori pengembangan wilayah yang dapat dijadikan acuan dalam rangka penataan ruang. Teori-teori pengembangan wilayah teresebut menganut berbagai azas atau dasar dari tujuan penerapan masing-masing teori. Jika dikelompokkan berdasarkan tujuan, teori-teori pembangunan bisa dikelompokkan kedalam empat kelompok. Kelompok pertama adalah teori yang memberi penekanan kepada kemakmuran wilayah (local prosperity). Kelompok kedua menekankan pada sumberdaya lingkungan dan faktor alam yang dinilai sangat mempengaruhi keberlanjutan sistem kegiatan produksi di suatu daerah (sustainable production activity). Kelompok ini sering disebut sebagai sangat perduli dengan pembangunan berkelanjutan (sustainable development). Kelompok ketiga memberikan perhatian kepada kelembagaan dan proses pengambilan keputusan di tingkat lokal sehingga kajian terfokus kepada governance yang bisa bertanggung jawab (resposnsible) dan berkinerja bagus (good). Kelompok keempat perhatiannya tertuju kepada kesejahteraan masyarakat yang tinggal di suatu lokasi (people prosperity).

Di Indonesia perkembangan konsep perencanaan wilayah merupakan aplikasi dari teori yang dikembangkan oleh beberapa orang pakar diantaranya, Walter Isard, Albert O. Hirschman, Gunnar Mydar, John Friedmann dan Mike Douglass. Sementara dari Indonesia sendiri muncul gagasan pengembangan wilayah dari Sutami, Poernomosidhi dan Ruslan Diwiryo.

Walter Isard sebagai pelopor Ilmu Wilayah yang mengkaji terjadinya hubungan sebab-akibat dari faktor-faktor utama pembentuk ruang wilayah, yakni faktor fisik, sosial-ekonomi, dan budaya ${ }^{3}$. Hirschman (era 1950-an) memunculkan teori polarization effect dan trickling-down effect dengan argumen bahwa perkembangan suatu wilayah tidak terjadi secara bersamaan (unbalanced development).

Gunnar Myrdal (era 1950-an) mengemukakan teori yang menjelaskan hubungan antara wilayah maju dan wilayah belakangnya dengan menggunakan istilah backwash and spread effect. Friedmann (era 1960-an) lebih menekankan pada pembentukan hirarki guna mempermudah pengembangan sistem pembangunan yang kemudian dikenal dengan teori pusat pertumbuhan ${ }^{4}$. Mike Douglass (era 70-an) yang memperkenalkan lahirnya model keterkaitan desa kota (rural-urban linkages) dalam pengembangan wilayah. Dalam pembangunan wilayah di Indonesia, pemikiran Douglas ini sekarang dikenal dengan konsep Agropolitan.

Keberadaan landasan teori dan konsep pengembangan wilayah diatas kemudian diperkaya dengan gagasan-gagasan yang lahir dari pemikiran 
cemerlang putra-putra bangsa, diantaranya adalah Ir. Sutami (era 1970-an) dengan gagasan bahwa pembangunan infrastrukturyang intensif untuk mendukung pemanfaatan potensi sumberdaya alam akan mampu mempercepat pengembangan wilayah. Poernomosidhi (era transisi) memberikan kontribusi lahirnya konsep hirarki kota-kota dan hirarki prasarana jalan melalui Orde Kota.

Selanjutnya adalah Ruslan Diwiryo (era 1980-an) yang memperkenalkan konsep Pola dan Struktur ruang yang bahkan menjadi inspirasi utama bagi lahirnya UU No.24/1992 tentang Penataan Ruang yang kemudian digantikan dengan Undang-Undang No.26/2007. Pada periode 1980-an ini pula, lahir Strategi Nasional Pembangunan Perkotaan (SNPP) sebagai upaya untuk mewujudkan sitem kota-kota nasional yang efisien dalam konteks pengembangan wilayah nasional. Dalam perjalanannya SNPP ini pula menjadi cikal- bakal lahirnya konsep Program Pembangunan Prasarana Kota Terpadu (P3KT) sebagai upaya sistematis dan menyeluruh untuk mewujudkan fungsi dan peran kota yang diarahkan dalam SNPP.

Pada era 90-an, konsep pengembangan wilayah mulai diarahkan untuk mengatasi kesenjangan wilayah, misal antara KTI dan KBI, antar kawasan dalam wilayah pulau, maupun antara kawasan perkotaan dan perdesaan (sebagai bias dari adopsi teori Hirschman dan Myrdal?). Perkembangan terakhir pada awal abad millennium, bahkan, mengarahkan konsep pengembangan wilayah sebagai alat untuk mewujudkan integrasi Negara Kesatuan Republik Indonesia. Konsep pengembangan wilayah yang terakhir ini juga tidak terlepas dari sesat pikir perencanaan pembangunan regional yang dilakukan selama ini dimana konsepsi bahari tidak dipandang sebagai kesatuan dalam konsep pembangunan wilayah ${ }^{5}$.

Di Indonesia, berbagai konsep nomenklatur kewilayahan seperti "Wilayah", "Kawasan", "Daerah", "Regional", "Area", "Ruang", dan istilahistilah sejenis, banyak dipergunakan dan dapat saling dipertukarkan pengertiannya walaupun masing-masing memiliki bobot penekanan pemahaman yang berbedabeda, tetapi semuanya berasal dari bahasa Inggris yaitu region. Namun demikian, konsepsi wilayah saat ini dapat diacu pada Undang-Undang Nomor 26 Tahun 2007 tentang Penataan Ruang.

Menurut Undang-Undang No. 26 Tahun 2007 tentang Penataan Ruang, pengertian wilayah adalah "ruang" yang merupakan kesatuan geografis beserta segenap unsur terkait yang batas dan sistemnya ditentukan berdasarkan aspek administrasi dan atau aspek fungsional. Berdasarkan pengertian undang-undang tersebut, ada dua aspek yang harus diperhatikan dalam konsep wilayah, yaitu : pertama, di dalam wilayah ada unsur-unsur yang saling terkait yaitu ruang yang berfungsi lindung yang harus selalu dijaga keberadaannya dan ruang yang berfungsi budidaya sebagai tempat manusia melakukan kegiatannya untuk kelangsungan hidupnya, yang pada dasarnya keduanya tidak dapat hidup dan berkembang serta survive (keberlanjutan) sendiri-sendiri. Kedua, adanya pengertian deliniasi fungsi berdasarkan koordinasi geografis (batasan berdasarkan titik-titik koordinat) yang deliniasinya bisa wilayah administrasi (pemerintahan) atau wilayah fungsi tertentu lainnya.

Oleh karenanya, berdasarkan UU No. 26/2007, Wilayah harus dibangun karena secara memiliki fungsi lindung dn fungsi budidaya. Menurut 
Djakapermana (2010), pengembangan wilayah pada dasarnya mempunyai tujuan agar wilayah itu berkembang menuju tingkat perkembangan yang diinginkan.

Pengembangan wilayah dilaksanakan melalui optimasi pemanfaatan sumber daya yang dimilikinya secara harmonis, serasi dan terpadu melalui pendekatan yang bersifat komprehensif mencakup aspek fisik, ekonomi, sosial, budaya, dan lingkungan hidup untuk pembangunan berkelanjutan. Sementara menurut Sementara menurut Zen (2001) berpendapat bahwa pengembangan wilayah tidak lain dari usaha mengawinkan secara harmonis sumber daya alam, manusianya, dan teknologi, dengan memperhitungkan daya tampung lingkungan itu sendiri.

Dalam perkembangannya, pembangunan wilayah di Indonesia mengalami proses yang berkelanjutan seusia dengan tuntutan pembangunan itu sendiri. Namun demikian, tanpa disadari pembangunan wilayah masih menyisakan berbagai persoalan, diantaranya :

1. Ketimpangan Wilayah (Regional Disparity). Agaknya, paham dualisme yang dikembangkan oleh ahli ekonomi pembangunan masih kental mewarnai pembangunan wilayah di Indonesia. Studi Nurzaman (1997) menunjukkan secara nyata adanya ketimpangan pembangunan antara Kawasan Barat Inonesia (KBI) dan Kawasan Timur Indonesia (KTI) terutama dalam bidang ekonomi. Lampiran-1, menunjukkan bagaimana kesenjangan wilayah di Indonesia pada tahun 2008. Hal ini masih berlangsung sampai saat ini. Data PDB nasional menunjukkan Pulau Jawa masih sangat dominan pengaruhnya terhadap perekonomian nasional. Sebesar 57,51 persen dari PDB Indonesia disumbang oleh Pulau Jawa, dengan urutan tiga provinsi terbesarnya yaitu DKI Jakarta $(16,76 \%)$, Jawa Timur $(14,89 \%)$, dan Jawa Barat $(13,91 \%)$. Sementara untuk Pulau Sumatera sumbangan terbesar berasal dari Propinsi Riau (7,08\%), Sumatera Utara $(5,30 \%)$ dan Sumatera Selatan (3,05\%). Secara kuantitatif, kegiatan-kegiatan di sektor sekunder dan tersier masih terkonsentrasi di Pulau Jawa, sedangkan kegiatan sektor primernya lebih diperankan oleh luar Pulau Jawa. Pada Triwulan IV 2012, apabila pengelompokan kegiatan ekonominya dibedakan ke dalam tiga sektor utama yaitu sektor primer, sektor sekunder dan sektor tersier, maka secara spasial sektor primer lebih didominasi oleh wilayah luar Jawa (74,20\%). Sedangkan untuk sektor sekunder dan tersier, Pulau Jawa masih menjadi penyumbang terbesar yaitu masing-masing sebesar $65,94 \%$ dan $66,15 \%$. Dari sisi ini terlihat bahwa perdagangan terjadi di blok ekonomi utama yaitu Pulau Jawa dan Pulau Sumatera sementara pada pulau-pulau lain seperti di Kalimantan, Sulawesi, Nusa Tenggara, Maluku, dan Papua masih relatif kecil dan belum berkembang.

2. Keterkaitan Desa-Kota (Rural-Urban Linkage). Kawasan perkotaan dan perdesaan merupakan lanskap wilayah yang saling berhubungan melalui kertaikan hubungan ekonomi, sosial dan politik serta lingkungan yang sangat komplkes (Sugiana, 2005). Perkembangan desa sangat dipengaruhi oleh perkembangan kota, demikian juga morfologi kota sangat dipengaruhi oleh perkembangan desa. Namun demikian, dalam perkembangannya keterkaitan desa kota menimbulkan masalah dalam bentuk penghisapan sumber daya. 
Kota menarik semua variabel produksi desa yang akhirnya menimbulkan ketimpangan pembangunan antara desa dan kota. Dengan kata lain, perkembangan pembangunan kota yang pesat telah merubah wajah desa. Studi Wilonoyudho (2009) menunjukkan di Indonesia yang terjadi malahan keterkaitan konsumsi (consumption linkage). Artinya kota-kota besar di Indonesia menjadi "parasit" dan menyedot sumberdaya desa secara gila- gilaan. Tetesan kebawah (trickle down effect) dan sebaran kemakmuran (spread effect) tidak terjadi ${ }^{6}$. Akibatnya dapat diduga, arus migrasi dari desa ke kota di negeri ini luar biasa. Pada tahun 2008 misalnya, provinsi Jawa

Tengah mengirimkan 13.000 tenaga kerja ke Jakarta dalam arus balik lebaran. Ini artinya, desa-desa di tanah air mengalami kelangkaan kesempatan kerja. Justru produk-produk moderen dari kota dan dari pusat kapitalisme dunia deras mengalir ke desa. Hadirnya puluhan stasiun TV swasta, makin menyuburkan pola konsumsi masyarakat desa. Pada tahun 2008 juga merupakan tahun yang sangat istimewa bagi Indonesia karena pertama kalinya dalam sejarah peradaban modern Indonesia, jumlah penduduk kota $(50,5 \%)$ melebihi jumlah penduduk desa (49,5\%). Fenomena ini memunculkan peningkatan populasi di perkotaan yang akhirnya menjadi tekanan bagi perkembangan kota. Dampak industrialisasi dan urbanisaasi telah juga menyebabkan terjadinya degradasi lingkungan perkotaan.Degradasi kualitas lingkungan di Indonesia berlangsung lebih cepat dari peningkatan tingkat kesejahteraan. Banjir, kawasan kumuh, krisis air bersih dan sebagainya merupakan contoh dari industrialisasi dan degradasi lingkungan ini. (Depertemen PU, 2008). Kompleksitas persoalan perkotaan juga bertambah sebagai akibat adanya otonomi daerah dan demokratisasi pembangunan. Krisis ideologi kepentingan publik, konflik kewenangan (pusat dan daerah), pembentukan kota-kota baru (implikasi dari pemekaran daerah), krisis lintas wilayah, krisis perbatasan (TPA, terminal dll) merupakan bentuk permasalahan perkotaan yang muncul sebagai derivatif dari otonomi daerah.

3. Ketimpangan pendapatan antar wilayah. Salah satu bias dari ketimpangan pembangunan antar wilayah adalah ketimpangan pendapatan antar wilayah. Dilihat dari sisi PDRB per kapita per propinsi (2000-2005), terjadi ketimpangan besar. PDRB per kapita yang tinggi terpusat pada daerah kaya sumber daya seperti Kaltim, Riau, Papua, dan NAD, serta daerah ibukota. Data Susenas 2012 menunjukkan Indeks koefisien gini tahun 2008 sebesar 0,35 meningkat menjadi 0,41 pada tahun 2012. Indeks koefisien gini tertinggi $(0,44)$ terdapat di Provinsi Gorontalo dan Papua, sementara yang terendah terjadi di Kepulauan Bangka Belitung $(0,29)^{\top}$. Walaupun dari segi teori, angka gini sebesar 0,41 dikategorikan sebagai ketimpangan sedang, namun peningkatan angka gini dari tahun 2002 perlu mendapat perhatian yang serius. Di sisi lain, pertumbuhan Indonesia belum berada pada jalur yang benar, karena pendapatan nasional sebagai bentuk kue nasional dinikmati oleh $40 \%$ dari golongan pendapatan menengah dan $20 \%$ oleh golongan pendapatan teratas. Sementara itu, 40\% dari golongan pendapatan terendah mengalami penurunan selama periode 2002-2007. Periode 2002- 
2007 menunjukkan betapa 20\% golongan teratas penduduk meningkat secara signifikan. Ketimpangan pendapatan terutama pendapatan antara wilayah memunculkan daerah tertinggal ${ }^{8}$. Hingga tahun 2012 masih ada 183 kabupaten daerah tertinggal di Indonesia yang 70 persen di antaranya di Kawasan Timur Indonesia (KTI ${ }^{9}$. Sebaran 183 kabupaten daerah tertinggal di 27 provinsi minus Jambi, Riau, DKI Jakarta, Jawa Tengah, DI Yogyakarta, dan Sulawesi Barat, yaitu 46 di Sumatera, 9 di Jawa, 16 di Kalimantan, 34 di Sulawesi, 28 di Bali Nusa Tenggara, 15 di Maluku dan Maluku Utara, serta 35 di Papua dan Papua Barat. Totalnya, 128 kabupaten daerah tertinggal atau sekitar 70 persen di KTI. Provinsi yang jumlah kabupaten daerah tertinggalnya terbanyak ialah Papua memiliki 27 daerah tertinggal, Nusa Tenggara Timur (20), Kalimantan Barat dan Sulawesi Tengah (masingmasing 10), Sulawesi Tenggara (9), serta Sumatera Barat, Nusa Tenggara Barat, Maluku, dan Papua Barat (masing-masing 8).

4. Kemiskinan. Pada sisi lain, jumlah orang miskin masih cukup merisaukan. Sebanyak $11,66 \%$ penduduk masih dalam kategori miskin yang teresebar di seluruh wilayah Indonesia. Penyebaran penduduk miskin didominasi oleh daerah perdesaan. Jumlah penduduk miskin tertinggi berada di Propinsi Papua (30,66\%) dan Papua Barat (27,04\%). Sejalan dengan pergesaran paradigma pembangunan, hasil kajian menunjukkan bahwa tidak terdapat korelasi yang positip antara kemajuan ekonomi dan tingkat kesejahteraan rakyat yang diukur dalam konsep Indeks Pembangunan Manusia (IPM) diantaranya penelitian Gustav Ranis \& Frances Stewart (2002) dan Valeria Constantini dan Salvatore Monni (2006). Kondisi ini juga berlaku di Indonesia. Daerah yang memiliki pendapatan perkapita tinggi tidak menunjukkan hubungan yang searah dengan IPM. Dengan lain perkataan, perkembangan IPM regional dan pendapatan regional domestik bruto (PDRB) relatif tidak seirama. Perkembangan PDRB yang tinggi tidak selalu diikuti oleh perkembangan IPM yang tinggi pula. Sebaliknya, pertumbuhan PDRB yang rendah belum tentu diikuti oleh perkembangan IPM yang rendah pula. Sebagai contoh pada tahun 2006, Provinsi DIY memiliki prestasi terbaik dalam menerjemahkan pertumbuhan ekonomi ke dalam pembangunan manusia, dengan hanya urutan 17 pada PDRB per kapita tetapi mencapai urutan 4 pada IPM. Sebaliknya, provinsi Papua dengan PDRB menempati urutan 4, tetapi hanya menempati urutan IPM paling rendah. Ini adalah bukti bahwa sumber daya alam yang begitu besar yang dimiliki Provinsi Papua tidak dinikmati oleh sebagian besar rakyatnya (Gintings, 2008). Menurut Kuncoro (2009) salah satu sebab munculnya daerah tertinggal ini adalah rendahnya IPM disamping terbatasnya infrastruktur dan kemampuan keuangan daerah.

\section{Pembangunan Wilayah: Amanah RPJMN (2010-2014)}

Kesenjangan antar daerah dalam indikator kesehatan, termasuk distribusi sumber daya manusia di bidang kesehatan (HRH) tetap menjadi perhatian yang serius. Pasokan tenaga kesehatan di fasilitas umum telah meningkat sejak pertengahan 1990-an, yang mencerminkan perhatian pemerintah untuk 
peningkatan akses ke pelayanan kesehatan, terutama di daerah terpencil dan terlayani, dan mencerminkan peningkatan jumlah sekolah kebidanan dan keperawatan dalam beberapa tahun terakhir. Sekitar 50.000 bidan dan perawat sekarang sedang diproduksi setiap tahun. Sementara jumlah dan rasio tenaga kesehatan telah meningkat, penyebaran praktik dan distribusi tidak merata tetap menjadi perhatian serius. Selain itu, peningkatan pesat dalam jumlah telah menimbulkan kekhawatiran tentang kualitas mereka, dan terutama kecukupan standar akreditasi dan sertifikasi serta kesiapan mereka untuk mengambil tanggung jawab di lingkungan pedesaan yang sering jauh dari rumah sakit universitas dan sekolah keperawatan dan kebidanan dari mana mereka lulus (Hattari; 20120)

Berbagai alternatif penyelesaian persoalan pembangunan wilayah di Indonesia telah banyak dilakukan utamanya oleh pemerintah. Rencana Pembangunan Jangka Menengah Nasional 2010-2014 telah menetapkan strategi dan kebijakan pengembangan wilayah yaitu:

1. Mendorong pertumbuhan wilayah-wilayah potensial di luar JawaBali dengan tetap menjaga momentum pertumbuhan di wilayah Jawa-Bali.

2. Meningkatkan keterkaitan antarwilayah melalui peningkatan perdagangan antar wilayah untuk mendukung perekonomian domestik.

3. Meningkatkan daya saing daerah melalui pengembangan sektorsektor unggulan di tiap wilayah.

4. Mendorong percepatan pembangunan daerah tertinggal, kawasan strategis dan cepat tumbuh, kawasan perbatasan, kawasan terdepan, kawasan terluar, dan daerah rawan bencana; serta

5. Mendorong pengembangan wilayah laut dan sektor-sektor kelautan.

\section{Reorientasi Pembangunan: Negara Kesejahteraan, Dari Pembangunan Nasional Ke Pembangunan Wilayah}

Menurut Dedi M, Masykur (2000) perencanaan pembangunan wilayah ditujukan untuk mengupayakan keserasian dan keseimbangan pembangunan antar daerah sesuai dengan potensi alamnya dan memanfaatkan potensi tersebut secara efisien, tertib dan aman. Sementara menurut Sjafrizal (2012) kebjakan pembangunan wilayah pada dasarnya merupakan keputusan dan intervensi pemerintah, baik secara nasional maupun regional untuk mendorong proses pembangunan daerah secara keseluruhan. Kebijakan pembangunan, dalam arti seluas-luasnya bertujuan untuk meningkatkan kesejahteraan.

Dalam konteks Negara Indonesia, Undang-Undang Dasar 1945 memuat tujuan (visi) dan misi abadi bangsa Indonesia. Visi abadi yang dimaksud sebagaimana tercantum dalam pembukaan UUD 1945 ialah "Negara Indonesia yang merdeka, berdaulat, adil dan makmur". Sedangkan misinya adalah pertama, melindungi segenap bangsa Indonesia; kedua, memajukan kesejahteraan umum; ketiga, mencerdaskan kehidupan bangsa, dan keempat, ikut melaksanakan ketertiban dunia berdasarkan kemerdekaan, perdamaian abadi dan keadilan sosial. Penjabaran visi dan misi tersebut diatas yang menyangkut kesejahteraan 
masyarakat kemudian dituangkan dalam pasal-pasal UUD 1945 yang berkenaan dengan kesejahteraaan.

Dalam kamus bahasa Indonesia, kesejahteraan diartikan sebagai hal atau keadaan sejahtera; keamanan, keselamatan, ketenteraman. Sementara sejahtera didefinisikan sebagai aman sentosa dan makmur; selamat (terlepas dari segala macam gangguan). Manakala kata sejahtera diartikan sebagai banyak hasil atau serba kecukupan. Kata kesejahteraan selalu didekatkan dengan kata kemakmuran. Dalam konteks ini, terdaat peranan negara dalam menghadirkan kesejahteraan. Peran negara terhadap kesejahteraan rakyat dituangkan dalam pasal-pasal UUD 1945 berikut :

Pasal 27 (ayat 2):

...(2) Tiap-tiap warga negara berhak atas pekerjaan dan penghidupan yang layak bagi kemanusiaan.

\section{Pasal 33 (ayat 1, 2 dan 3)}

1. Perekonomian disusun sebagai usaha bersama berdasar atas asas kekeluargaan.

2. Cabang-cabang produksi yang penting bagi negara dan yang menguasai hajat hidup orang banyak dikuasai oleh negara.

3. Bumi dan air dan kekayaan alam yang terkandung di dalamnya dikuasai oleh negara dan dipergunakan untuk sebesar-besar kemakmuran rakyat.

\section{Pasal 34 (ayat 1)}

Fakir miskin dan anak terlantar dipelihara oleh negara.

Pasal 33 ayat (1) UUD 1945 yang mengatur tentang perekonomian dapat diartikan bahwa perkonomian secara imperatif harus disusun, tidak dibiarkan tersusun sendiri sesuai dengan kehendak dan perilaku para penguasa. Ketimpangan yang muncul harus direstruktur dengan campur tangan pemerintah, agar daulat pasar tidak menggusur daulat rakyat. Pasal 33 UUD 1945 mencerminkan adanya demokrasi ekonomi dan demokrasi

Indonesia berdasar pada faham kebersamaan dan asas kekeluargaan (mutualism dan brotherhood alias berjamaah dan berukhuwah ${ }^{10}$. Esensi kata bumi, air dan kekayaan alam menunjukkan bahwa negara memiliki wilayah yang terdiri dari bumi, air dan kekayaan alam yang digunakan untuk sebesar-besar kemakmuran rakyat.

Dalam menyusun kebijakan pembangunan wilayah perlu ditetapkan dua alternatif sasaran yaitu kemakmuran wilayah (place prosperity), kemakmuran masyarakat (people prosperity) atau keduanya sekaligus. Bila kemakmuran wilayah yang menjadi sasaran, maka hasilnya adalah kondisi fisik wilayah seperti sarana, prasarana dan perumahan, fasilitas pelayanan sosial, kualitas lingkungan hidup dan sebagainya yang akan menjadi tujuan. Membaiknya kemakmuran wilayah ini akan meningkatkan pertumbuhan ekonomi wilayah, namun kondisi ini memerlukan investasi yang besar. Kemajuan ekonomi menyebabkan akan terjadinya proses migrasi sebagai akibat terbuka lapangan kerja. Namun demikian, kondisi ini akan dinikmati oleh kaum pendatang 
(sebagai akibat kualitas kaum pendatang lebih baik) yang akirnya akan menciptakan ketimpangan pendapatan (income disparity).

Sebaliknya bila sasaran utama adalah kemakmuran rakyat (people prosperity), maka yang menjadi sasaran adalah pembangunan masyarakat. Kegiatan pembangunan yang akan dilakukan akan bertumpu pada pengembangan penddikan, peningkatan pelayanan kesehatan, penerapan telnologi dan peningkatan produksi dan sebagainya. Intinya adalah bagaimana memberdayakan masyarakat dalam segala bidang. Di satu sisi pengeluaran investasi infrastruktur dibutuhkan untuk memfasilitasi pertumbuhan ekonomi, namun di sini lain diperlukan juga investasi untuk meningkatkan kualitas sumber daya manusia. Meningkatnya perbaikan modal manusia sebetulnya juga memberikan manfaat positif bagi pertumbuhan ekonomi melalui tersedianya tenaga kerja yang berkualitas (Sjafii, 2009). Hasil kebijakan pembangunan yang berorentasi kemakmuran rakyat ini biasanya tidak secepat dan semaju dibandingkan dengan kebijakan kemakmuran wilayah.

Dalam konteks pembangunan wilayah (baca daerah), perlu dilakukan tiga pendekatan strategi pokok yaitu: pendekatan spasial (spatial approach), pendekatan sektoral (sectoral approach) dan pendekatan manusia (human approach). Keitga pendekatan ini harus dilakukan secara terpadu dan melalui alokasi investasi secara regional. Pada strategi berdimensi spasial perlu menitikberatkan pada strategi pengembangan perkotaan, pengembangan perdesaan, dan pengembangan wilayah. Pada tingkat kota adalah dengan memanfaatkan jaringan kota-kota yang ada yaitu dengan mengembangkan kota kelas dua dan kota-kota baru (sebagai dampak dari pemekaran wilayah).

Pengembangan perdesaan dilakukan melalui pemberdayaan masyarakat desa, pengembagan desa pantai, merevitalisasi modal sosial masyarakat lokal, peningkatan keterkaitan antara desa-kota dan pengembangan ekonomi lokal. Sementara pada tingkat wilayah adalah dengan memanfaatkan kecamatan sebagai pusat pertumbuhan yang berbasis pada keunggulan komparatip. Pembangunan wilayah dilakukan dengan menciptakan pusat-pusat kegiatan ekonomi baru terutama di luar Jawa dan meningkatkan keterkaitan wilayah- wilayah ekonomi unggulan di luar Pulau Jawa.

Ketiga strategi ini bermuara pada strategi pengembangan kawasan berbasis kluster $^{11}$. Di sisi lain, perkembangan wilayah perlu juga memperhatikan penetapan wilayah pembangunan dengan memperhatikan aspek kesamaan kondisi (homogenous region), aspek keterkaitan antar daerah (nodal region), aspek kesamaan kondisi geografis antar wilayah (functional region) dan aspek kesatuan administrasi wilayah pemerintahan (planning region).

Pendekatan sektoral pada intinya memperhatikan dan memprioritaskan subsektor kunci yang ada di wilayah. Pendekatan ini dilakukan atas dasar kompetensi inti dan produk unggulan yang ada di masing-masing daerah. Oleh karenanya perlu dipertimbangkan konsep regionalisasi produk. Sampai saat ini dan beberapa tahun ke depan, struktur ekonomi bebrapa daerah di Indonesia Papua, Kaltim, Riau, Aceh masih berbasis tambang, minyak dan gas serta sektor industri dan jasa yang terkait tambang dan migas. Sebagai sumberdaya tak terbaharui (non renewable resources) tambang, minyak dan gas tersebut di masa 
yang akan datang akan habis. Oleh karenanya, daerah penghasil tambang tersebut harus sedini mungkin mempersiapkan sektor utama baru yang berbasis pada sumberdaya alam yang terbaharui (renewable resources) yang potensial yakni agribisnis (dalam arti luas).

Pada pendekatan manusia, penekanan investasi pada manusia diyakini merupakan basis dalam meningkatkan produktivitas faktor produksi secara total. Kualitas manusia yang meningkat merupakan prasyarat utama dalam proses produksi dan memenuhi tuntutan masyarakat industrial. Penempatan manusia sebagai subyek pembangunan menekankan pada pentingnya pemberdayaan (empowerment) manusia, yaitu: kemampuan manusia untuk mengaktualisasikan segala potensinya. Peningkatan mutu SDM mencakup dalam 5 aspek yakni peningkatan mutu pendidikan ${ }^{12}$, peningkatan kualitas Pelayanan kesehatan, peningkatan akhlak dan agama, peningkatan kualitas ketenagakerjaan dan aparatur pemerintah, dan kependudukan. Hubungan antara tingkat pendidikan inilah yang akan menjadi modal dasar bagi peningkatan ekonomi.

\section{KESIMPULAN}

1. Dalam suatu proses pembangunan, unsur pertumbuhan dan perubahan (growth and change) akan terjadi secara simultan. Ciri dan kecepatan perubahan tidak sama antara negara-negara manapun antara satu periode dengan periode yang lain di suatu negara.Menterjemahkan perkembangan masa lalu ke perencanaan masa depan sangatlah tidak mudah dan tidak dapat dilakukan begitu saja. Di satu pihak berbagai faktor ketidakpastian (uncertainities) cukup banyak dan sulit diperhitungkan dalam lingkungan dunia yang semakin kompleks. Namun, merencanakan sesuatu berdasarkan semata-mata perkembangan masa lalu, tidak ubahnya dengan "merencanakan masa lalu". Jadi, kesimpulan antara pengalaman, ketajaman visi dalam melihat faktor penting di masa depan serta peningkatan kemampuan atau kualitas metodologi perencanaan akan merupakan tuntutan masa depan (Iwan Jaya Azis, 1990).

2. Proses pembangunan adalah upaya menciptakan perubahan ke arah yang diinginkan dan direncanakan. Pada masa lalu, pembangunan diartikan sebagai sebagai suatu proses untuk meningkatkan pertumbuhan ekonomi semata. Munculnya ilmu-ilmu kewilayahan, khususnya regional development dan regional sciences merupakan bentuk-bentuk kritik atas cara pandang terhadap pendekatan pembangunan yang terlalu sering melihat dari kacamata makro (pembangunan nasional), sedangkan salah satu permasalahan riil pembangunan adalah masalah ketimpangan wilayah (regional disparity).

3. Ketimpangan (wilayah) muncul sebagai akibat dari proses adopsi konsep Simon Kuznets (1966) melalui The First Fundamental Theorem of Welfare Economics. Melalui konsep ini Kuznets menjelaskan kurva U-terbalik; yang menyatakan bahwa bagi negara yang pendapatannya rendah, pertumbuhan ekonomi harus mengorbankan pemerataan (trade off antara pertumbuhan dan pemerataan). Pemahaman seperti ini telah memberi legitimasi dominasi peranan pemerintah untuk 
memusatkan pengalokasian sumberdaya pada sektor-sektor atau wilayah-wilayah yang berpotensi besar dalam menyumbang pada pertumbuhan ekonomi ${ }^{13}$.

4. Pembangunan wilayah bukanlah semata-mata fenomena dalam dimensi lokal dan regional namun juga merupakan bagian tak terpisahkan dari kepentingan pembangunan nasional bahkan global. Konsepsi tiada negara tanpa wilayah, tiada negara tanpa rakyat, agaknya perlu dijadikan dasar dalam pengembangan pembangunan wilayah di masa depan.

5. Permasalahan pokok yang harus dipecahkan dalam konsepsi pembangunan wilayah adalah adanya keinginanyangkuatuntuk menghadirkankesejahteraan (welfare) dengan mengurangi ketimpangan wilayah (disparity); baik disparity between region maupun disparity within region untuk jangka waktu yang panjang. Keinginan ini harus dilandasi oleh doktrin kesejahteraan wilayah dan doktrin kesejahteraan rakyat (sosial) yang didukung oleh sistem ekonomi politik negara yang memihak pada keadulatan rakyat (berdasar atas asas kekeluargaan). Merubah paradigma pembangunan nasional menjadi keunggulan wilayah (daerah) merupakan jalan yang harus ditempuh. Paradigma ini akhinya akan menghantarkan kita menjadi welfare state.

\section{DAFTAR PUSTAKA}

Alkadri, Muchdie dan Suhandojo, 2001. Tiga Pilar Pengembangan Wilayah: Sumber Daya Alam, Sumber Daya Manusia, dan Teknologi. Direktorat Kebijaksanaan Teknologi untuk Pengembangan Wilayah Badan Pengkajian dan Penerapan Teknologi. Jakarta.

Anwar, Effendi dan Rustiadi, Ernan, 2003. Alternatif Sistem Perencanaan Pembangunan Bagi Indonesia di Masa Depan. Makalah disampaikan pada Seminar Nasional "Sistem Perencanaan Pembangunan Nasional dan Ekonomi Politik Baru Pasca UUD 1945 dan Peresmian Himpunan Perencana Pembangunan Wilayah dan Perdesaan (HPWD)". Jakarta, 2 Juli.

Azis, Iwan Jaya,(1990) Transformasi Ekonomi Indonesia dan Prognosa Masa Depan, Makalah yang disampaikan pada Simposium Nasional "Menuju Masayarakat Indonesia Abad XXI" yang dilaksanakan oleh ICMI pusat, Jakarta.

Azis, Iwan Jaya,1994. Ilmu Ekonomi Regional dan Beberapa Aplikasinya di Indonesia, Lembaga Penerbit Fakultas Ekonomi Universitas Indonesia, Jakarta. 
Riyadi,Dedi M. Masykur, 2000. Pembangunan Daerah Melalui Pengembangan Wilayah, Makalah yang disampaikan pada Diseminasi dan Diskusi Program-Program Pengembangan Wilayah dan Pengembangan Ekonomi Masyarakat di Daerah, Hotel Novotel, Bogor, 15-16 Mei Direktur Jenderal Penataan Ruang, 2003.

Pengembangan Wilayah dan Penataan Ruang di Indonesia: Tinjauan Teoritis dan Praktis, Makalah pada Stadium General Sekolah Tinggi Teknologi Nasional (STTNAS), Yogyakarta.

Gintings, Charisma Kuriata, 2008. Analisi Pembangunan Manusia di Indonesia, Tesis, Sekolah Pascasarjana Univeristas Sumatera Utara, Medan.

Issard, Walter, 1975. Introduction to Regional Science. Englewood Cliffs, N.J: Prentice-Hall.

M. Baiquni, 2005., Sesat Pikir Perencanaan Pembangunan Regional: Refleksi Kritis di Era Pembangunan Daerah. Forum Perencanaan

Pembangunan, Edisi Khusus, Januari.

Kuncoro, Mudradjad. 2005, PengantarPerencanaan Pembangunan Ekonomi Daerah, Edisi Kedua, Yogyakarta, BPFE UGM.

Kuncoro, Mudradjad. 2010, Masalah, Kebijakan dan Politik: Ekonomika Pembangunan, Jakarta: Penerbit Erlangga.

Nurzaman, Siti Sutriah.1997. Tinjauan Kesenjangan Wilayah di Indonesia. Jurnal Perencanaan Wilayah dan Kota. ITB. Vol. 8. No.4. pp.11-21.

Peraturan Presiden Republik Indonesia Nomor 5 Tahun 2010 tentang Rencana Pembangunan Jangka Menengah Nasional (RPJMN) Tahun 2010-2014.

Rustiadi, Ernan, 2001. Pergeseran Menuju Paradigma Baru Pembangunan Wilayah. Makalah yang disampaikan pada Forum Diskusi Pengembangan Metode, Puslitbang Ketenagakerjaan dan Ketransmigrasian, Departemen Tenagakerja dan Transmigrasi, 20 Agustus.

Rustiadi, Ernan, Sunsun Saefulhakim dan Dyah R. Panuju, 2011. Perencanaan dan Pengembangan Wilayah. Jakarta: Crespent Press dan Yayasan Pustaka Obor Indonesia.

Setiadi, Hafid, 2007. Pembangunan Wilayah: Gagasan Ruang Ekologis dan Pembangunan Berkelanjutan. Makalah yang disampaikan pada dalam Seminar Nasional "Pembangunan Wilayah Berwawasan Lingkungan" di Balai Senat Universitas Gadjah Mada Yogyakarta tanggal 27 Oktober. 
Sirojuzilam dan Kasyful Mahalli, 2011. Regional:

Pembangunan, Perencanaan dan Ekonomi. USU-Press. Medan.

Soegijoko, Budy Tjahjati, Gita Chandrika Napitupulu dan Wahyu Mulyana (Eds), 2005. Bunga Rampai Pembangunan kota Indonesia Dalam Abad I, Buku I Konsep dan Pendekatan Pembangunan Perkotaan di Indonesia, URDI dan Yayasan Sugijanto Soegijoko, Jakarta.

Sugiana, Kawik, 2005. Keterkaitan Desa kota di Indonesia, dalam Soegijoko, Budy Tjahjati, Gita Chandrika Napitupulu dan Wahyu Mulyana (Eds) (2005). Bunga rampai

Pembangunan kota Indonesia Dalam Abad I, Buku I Konsep dan Pendekatan Pembangunan Perkotaan di Indonesia, URDI dan Yayasan Sugijanto Soegijoko, Jakarta.

Sjafii, Achmad, 2009. Pengaruh Investasi Fisik dan Investasi Pembangunan Manusia Terhadap Pertumbuhan Ekonomi Jawa Timur 1990-2004. Journal of Indonesian Applied Economics. Vol. 3 No. 1 Mei 2009, 5976

Sjafrizal, 2012. Ekonomi Wilayah dan Perkotaan. PT. RajaGrafindo Persada, Jakarta.

Swasono, Sri Edi, 2010. Indonesia dan Doktrin Kesejahteraan Sosial: Dari Klasikal dan Neoklasikal sampai ke The End of LaissezFaire.

Perkumpulan PraKarsa. Jakarta. Tarigan, Robinson, 2004. Perencanaan Pembangunan Wilayah, Jakarta: PT. Bumi Aksara. 